\title{
Occupational lead poisoning in the United States: clinical and biochemical findings related to blood lead levels
}

\author{
E. L. BAKER, JR. ${ }^{* 1}$, P. J. LANDRIGAN ${ }^{1}, A$. G. BARBOUR ${ }^{1,5}$, D. H. COX ${ }^{2}$, \\ D. S. FOLLAND ${ }^{1,4}$, R. N. LIGO $^{3}$, AND J. THROCKMORTON ${ }^{5}$
}

From the ${ }^{1}$ Bureau of Epidemiology, the ${ }^{2}$ Bureau of Laboratories, and the ${ }^{3}$ National Institute for Occupational Safety and Health, Center for Disease Control, Atlanta, Georgia, the ${ }^{4}$ Tennessee Department of Public Health, Nashville, Tennessee, and the ${ }^{5}$ Utah Division of Health, Salt Lake City, Utah

ABSTRACT Dose-response relationships between blood lead levels and toxic effects have been evaluated in 160 lead workers in two smelters and a chemicals plant. Blood lead levels ranged from 0.77 to $13.51 \mu \mathrm{mol} / \mathrm{litre}(16-280 \mu \mathrm{g} / \mathrm{dl})$. Clinical evidence of toxic exposure was found in 70 workers $(44 \%)$, including colic in 33 , wrist or ankle extensor muscle weakness in 12 , anaemia $(\mathrm{Hgb}<8.69 \mu \mathrm{mol} /$ litre $(\mathrm{Hb} / 4)$ or $14.0 \mathrm{gm} / \mathrm{dl})$ in 27 , elevated blood urea nitrogen $(\geq 7 \cdot 14 \mathrm{mmol} /$ litre or $20 \mathrm{mg} / \mathrm{dl}$ ) in 28 , and possible encephalopathy in two. No toxicity was detected at blood lead levels below $1.93 \mu \mathrm{mol} /$ litre $(40 \mu \mathrm{g} / \mathrm{dl})$. However, $13 \%$ of workers with blood lead levels of 1.93 to $3.81 \mu \mathrm{mol} /$ litre $(40-79 \mu \mathrm{g} / \mathrm{dl})$ had extensor muscle weakness or gastrointestinal symptoms. Anaemia was found in $5 \%$ of workers with lead levels of $1.93-2.85 \mu \mathrm{mol} / \mathrm{litre}(40-59 \mu \mathrm{g} / \mathrm{dl})$, in $14 \%$ with levels of 2.90 to $3.81 \mu \mathrm{mol} /$ litre $(60-79 \mu \mathrm{g} / \mathrm{dl})$, and in $36 \%$ with levels $\geq 3.86 \mu \mathrm{mol} / \mathrm{litre}$ $(80 \mu \mathrm{g} / \mathrm{dl})$. Elevated blood urea nitrogen occurred in long-term lead workers. All but three workers with increased blood urea nitrogen had at least four years occupational lead exposure, and nine had received oral chelation; eight of this group had reduced creatinine clearance, and eight had decreased renal concentrating ability. These data support the establishment of a permissible biological limit for blood lead at a level between 1.93 and $2.90 \mu \mathrm{mol} /$ litre $(40-60 \mu \mathrm{g} / \mathrm{dl})$.

Despite the long recognition of the sources, symptoms, and means of preventing occupational lead poisoning, cases continue to occur in the United States. Levine et al. (1976) described an epidemic of lead poisoning at a scrap smelter in Alabama; between 1970 and 1971, eight of 37 workers developed colic, and another developed encephalopathy. Lilis et al. (1977) in Indiana, Winegar et al. (1977) in Minnesota, and Giguere et al. (1977) in Vermont, have described recent episodes of occupationally acquired lead poisoning in smelter and storage

*Present address: Occupational Health Program, Harvard School of Public Health, Boston, Massachusetts

Address for reprints: P. J. Landrigan, National Institute for Occupational Safety and Health, Cincinnati, Ohio 45226, USA

Received for publication 30 October 1978 Accepted for publication 13 December 1978 battery workers. Lead poisoning and increased lead absorption have been found also in the children of smelter workers (Baker et al., 1977) and in children living near primary lead smelters (Landrigan et al., 1975, 1976; Ordoñez et al., 1976).

In this report we describe three epidemiological investigations of occupational lead exposure and lead poisoning in the United States; two in smelters in which workers had acute high-dose exposure to lead, and the third in a lead chemicals plant where exposure was chronic. In each instance we evaluated dose-response relationships between blood lead levels and the clinical and biochemical manifestations of lead toxicity. We wanted particularly to determine whether the maintenance of workers' blood lead levels below a limiting value of either 2.41 or $2.90 \mu \mathrm{mol} /$ litre $(50$ or $60 \mu \mathrm{g} / \mathrm{dl}$ ) would serve to protect most workers against the toxic consequences of exposure to inorganic lead. 


\section{Background and methods}

\section{THE PLANTS}

The first plant evaluated was a secondary lead smelter in Memphis, Tennessee. In the 11 months preceding our investigation (October, 1975) this smelter had recovered 11500 tonnes of lead, principally from used storage batteries. The plant had been monitored by the State of Tennessee since its opening in 1948, and since 1951 had received 19 citations and enforcement notices for exceeding permissible air lead standards or for not providing workers with adequate respiratory protection.

The second plant, in Salt Lake City, Utah, was a smaller scrap smelter which had recovered 258 tonnes of lead in the six months preceding our investigation. Our evaluation (January 1976) followed the admission to hospital of seven workers with symptoms of acute lead poisoning. The acute episode had apparently resulted from a change in plant operations from antimony production to lead recovery without concurrent changes in plant ventilation.

The third plant studied was a lead chemicals factory in Joplin, Missouri, which produced lead oxides (red lead and litharge), lead peroxide, lead sulphate, lead silicate, and 'blue lead'. The plant had been inspected by the Occupational Safety and Health Administration (OSHA) in 1975 and was found to have air lead levels consistently above the recommended standard of $200 \mu \mathrm{g}$ lead $/ \mathrm{m}^{3}$ air. During our investigations in March and May 1976, we learned that the plant physician had as recently as January 1976 administered oral chelation therapy to asymptomatic workers with increased blood lead levels as well as to workers with symptoms of lead poisoning; workers with less than severe symptoms remained at their work during courses of chelation therapy.

ENVIRONMENTAL EVALUATIONS

At the Tennessee and Utah plants we obtained breathing-zone air samples for lead analysis using personal samplers attached to individual workers. In addition, at the Utah smelter we obtained background air samples in several plant areas using stationary monitors. Samples were collected and analysed according to methods described by OSHA (Occupational Safety and Health Administration, 1976). Air sampling was not extensive in either plant, but was intended to provide an approximate picture of the intensity of exposure to airborne lead.

\section{STUDY POPULATIONS}

The Tennessee plant employed 84 workers at the time of our evaluation, the Utah plant 20 , and the
Missouri plant 74. Personnel turnover rates at the smelters were high (median duration of employment in each was less than one year), while the work force at the chemical factory was more stable (median employment 20 years).

We conducted evaluations of 77 current workers in Tennessee $(92 \%)$, of all 20 in Utah $(100 \%)$, and of 53 in Missouri ( $72 \%$ ). In addition, we examined one recently discharged employee in Tennessee and nine workers who had been discharged during the month before our evaluation in Utah.

\section{WORKER EVALUATIONS}

Evaluations at each plant were undertaken on site during a one- to two-day period by personnel from the Center for Disease Control (CDC) and State and local health departments. Blood lead levels were not known at the time of these evaluations. Demographic data, a complete occupational history, a history of the occurrence in the preceding year of symptoms possibly related to lead exposure, a history of past episodes of lead poisoning and of chelation therapy, a history of possible extraoccupational exposures to lead, and histories of tobacco and alcohol consumption were obtained for each worker. Each worker was examined in a standard fashion by a physician who was not aware of the subject's exposure history. Examinations focused on the functioning of central and peripheral nervous systems and employed established techniques for the neurological examination (Medical Research Council, 1975). Any abnormal findings discovered during examination were required to be confirmed by a second physician; only those findings judged abnormal by both examiners were so recorded.

A venous blood sample was obtained from each worker for lead, haemoglobin, haematocrit, and erythrocyte protoporphyrin (EP) analyses; a leadfree tube was used for the lead sample. Serum samples were obtained for determination of blood urea nitrogen (BUN) levels.

\section{LABORATORY PROCEDURES}

Blood lead analyses of samples from the Tennessee and Missouri plants were performed by atomic absorption spectrophotometry (Sherfinski, 1974). The Tennessee samples were analysed at the CDC Toxicology Laboratory, and the specimens from Missouri at the NIOSH Western Area Occupational Health (WAHO) Laboratory. The blood samples from the Utah smelter were analysed at the Bureau of Laboratories, Utah Division of Health using the method of Keenan et al. (1963).

EP analyses of the samples from Tennessee were performed at the CDC Laboratories using a micro- 
method (Piomelli, 1973). EP analyses of the Missouri specimens were performed at Environmental Sciences Associates (Burlington, Massachusetts). EP was not determined in the Utah investigation.

QUALITY ASSURANCE PROCEDURES FOR BLOOD LEAD DETERMINATIONS

The CDC Toxicology Laboratory is a national and international reference centre for blood lead analysis (Center for Disease Control, 1975, 1976). In 1976 and 1977, the NIOSH WAHO Laboratory participated in a blood lead proficiency testing programme organised by CDC. For those years the WAHO Laboratory produced acceptable values (within $\pm 15 \%$ of reference mean values) on $38(90.5 \%)$ of 42 blood samples submitted through the programme. As an added check on the lead analyses performed for this study, duplicate aliquots of 30 of the Missouri blood samples were sent to both the WAHO and CDC Laboratories. The mean lead level for these aliquots in the WAHO Laboratory was $4.25 \mu \mathrm{mol} / \mathrm{litre}(88.1 \mu \mathrm{g} / \mathrm{dl})$, while that at CDC was $4.03 \mu \mathrm{mol} /$ litre $(83.5 \mu \mathrm{g} / \mathrm{dl})$; the correlation coefficient ( $r$ ) between the two sets of values was 0.90 .

The Utah State Laboratory did not participate in the CDC blood lead proficiency testing programme, but did exchange aliquots of samples from 15 of the workers tested in the Utah plant with the WAHO Laboratory; the mean values obtained on these aliquots in the two laboratories were 6.02 and $6.76 \mu \mathrm{mol} /$ litre $(124.8)$ and $140.0 \mu \mathrm{g} / \mathrm{dl})$, respectively; the coefficient of correlation between the two sets of values was 0.99 .

\section{Results}

ENVIRONMENTAL DATA

Environmental sampling data showed that workers at the Tennessee and Utah smelters were being exposed, at the times of our evaluations, to air lead concentrations in excess of the then current OSHA standard of $200 \mu \mathrm{g}$ lead $/ \mathrm{m}^{3}$ air (expressed as an $8 \mathrm{~h}$ time-weighted average, TWA). At the Tennessee plant, air samples on 16 production workers showed a range of breathing-zone lead exposures from $120 \mu \mathrm{g} / \mathrm{m}^{3}$ for a battery wrecker to $350 \mu \mathrm{g} / \mathrm{m}^{3}$ for two yard workers. At the Utah plant, the average air lead level in background samples collected in the plant office was $60 \mu \mathrm{g} / \mathrm{m}^{3}$, in the lunchroom 90 $\mu \mathrm{g} / \mathrm{m}^{3}$, and in the furnace room $100 \mu \mathrm{g} / \mathrm{m}^{3}$ with the furnace shut down, and $2650 \mu \mathrm{g} / \mathrm{m}^{3}$ during charging of the furnace. The mean breathing-zone air lead concentration (8h TWA) for an office worker was
$17 \mu \mathrm{g} / \mathrm{m}^{3}$, for two welders $700 \mu \mathrm{g} / \mathrm{m}^{3}$, and for two furnace workers $2660 \mu \mathrm{g} / \mathrm{m}^{3}$.

BLOOD LEAD DATA

Blood lead levels of workers at the three plants ranged from 0.77 to $13.51 \mu \mathrm{mol} /$ litre $(16-280 \mu \mathrm{g} / \mathrm{dl})$. Fifty-two $(67 \%)$ of the 78 workers evaluated in Tennessee, $44(83 \%)$ of the 53 tested in Missouri, and $23(79 \%)$ of the 29 studied in Utah had lead levels $\geq 2.90 \mu \mathrm{mol} /$ litre $(\geq 60 \mu \mathrm{g} / \mathrm{dl}) ; 26(33 \%)$, $13(31 \%)$, and $21(72 \%)$, respectively, had levels $\geq 3.86 \mu \mathrm{mol} /$ litre $(\geq 80 \mu \mathrm{g} / \mathrm{dl})$. Highest blood lead levels were found in maintenance and production workers (Table 1), lowest in office and laboratory

Table 1 Mean blood lead levels, by job category; Tennessee Smelter-November 1975

\begin{tabular}{lrll}
\hline Job category & No. of workers & \multicolumn{2}{l}{ Blood lead level } \\
\cline { 3 - 4 } & & $(\mu \mathrm{g} / \mathrm{dl})$ & $(\mu \mathrm{mol} / \mathrm{l})$ \\
\hline Office + laboratory & 14 & $41 \cdot 8$ & $2 \cdot 02$ \\
Floor supervisor & 5 & $49 \cdot 6$ & $2 \cdot 39$ \\
Production worker & 50 & $82 \cdot 6$ & $3 \cdot 99$ \\
Cleanup + maintenance & 9 & $87 \cdot 2$ & $4 \cdot 21$ \\
\hline
\end{tabular}

personnel. Blood lead levels at the two smelting plants rose with duration of employment, and levels $\geq 3.86 \mu \mathrm{mol} /$ litre $(\geq 80 \mu \mathrm{g} / \mathrm{dl})$ were not seen, except at the Utah smelter, in workers employed for less than two months.

\section{CLINICAL DATA}

Clinical manifestations of lead poisoning were evident at all three plants. In the smelters, with their poorly controlled air lead exposures and rapid labour turnover, symptoms tended to be relatively acute in nature, and symptom prevalence at the smelters increased with duration of employment. The dominant findings there were colic, gastrointestinal symptoms, anorexia, fatigue, myalgia, joint pain, and extensor muscle weakness (Table 2). Symptoms were particularly acute and severe at the Utah plant, and two workers in Utah had possible lead encephalopathy. One presented with acute confusion; the other, who had a past history of seizures, presented with a grand mal convulsion after having been seizure-free on anticonvulsant medication for the three preceding years. At the Missouri lead chemicals plant, symptoms were more chronic and the dominant findings were fatigue, joint pains, and myalgia. The most striking finding at the lead chemicals plant was a high prevalence of renal functional impairment. 
Table 2 Frequency of abnormal clinical findings in lead workers at 3 plants-United States, 1975, 1976

\begin{tabular}{|c|c|c|c|}
\hline Findings & $\begin{array}{l}\text { Tennessee } \\
\text { Smelter }(78) \dagger\end{array}$ & $\begin{array}{l}\text { Utah } \\
\text { Smelter (29) } \dagger\end{array}$ & $\begin{array}{l}\text { Missouri } \\
\text { Chemicals plant }(53) \dagger\end{array}$ \\
\hline $\begin{array}{l}\text { Fatigue } \\
\text { Colic } \\
\text { Gastrointestinal symptoms* } \\
\text { Anorexia } \\
\text { Myalgia } \\
\text { Joint pain } \\
\text { Objective tremor } \\
\text { Extensor muscle weakness } \\
\text { Possible encephalopathy } \\
\text { Anaemia } \\
\text { BUN elevation }\end{array}$ & $\begin{array}{r}19(24 \%) \\
13(17 \%) \\
17(22 \%) \\
18(23 \%) \\
15(29 \%) \\
22(28 \%) \\
2(3 \%) \\
10(13 \%) \\
0( \\
12(15 \%) \\
6(8 \%)\end{array}$ & $\begin{array}{r}8(28 \%) \\
19(66 \%) \\
18(62 \%) \\
12(41 \%) \\
7(24 \%) \\
4(14 \%) \\
4(14 \%) \\
0 \\
2(7 \%) \\
11(38 \%) \\
5(17 \%)\end{array}$ & $\begin{array}{r}19(36 \%) \\
1(2 \%) \\
3(6 \%) \\
-6(11 \%) \\
10(19 \%) \\
2(4 \%) \\
2(4 \%) \\
0( \\
4(8 \%) \\
17(32 \%)\end{array}$ \\
\hline
\end{tabular}

*Includes nausea, vomiting, diarrhoea, and constipation.

†Number of workers studied.

RELATION OF BLOOD LEAD LEVELS TO CLINICAL SIGNS AND SYMPTOMS

At both smelting plants a positive association was evident between the prevalence of clinical findings in workers and their blood lead levels. Workers who reported symptoms consistent with lead poisoning had significantly higher blood lead levels than workers at the same plant without such symptoms (Table 3). Further, a progressive increase in prevalence rates for symptoms and signs, with increases in blood lead levels, was noted at each plant (Figure 1). At the Tennessee plant (Table 4) no workers with blood lead levels below $1.93 \mu \mathrm{mol} / \mathrm{litre}(40 \mu \mathrm{g} / \mathrm{dl})$ had extensor muscle weakness or gastrointestinal symptoms, whereas $5(13 \%)$ of the 38 workers with lead levels of $1.93-3.81 \mu \mathrm{mol} /$ litre $(40-79 \mu \mathrm{g} / \mathrm{dl}) \mathrm{had}$ one or both of those findings, as did $14(54 \%)$ of the 26 workers with lead levels $\geq 3.86 \mu \mathrm{mol} /$ litre $(80 \mu \mathrm{g} / \mathrm{dl})$. At the Utah plant, symptoms were reported by three $(38 \%)$ of the eight workers with blood lead levels below $3.86 \mu \mathrm{mol} / \mathrm{litre}(80 \mu \mathrm{g} / \mathrm{dl})$, by seven $(78 \%)$ of the nine with levels of $3.86-4.78$

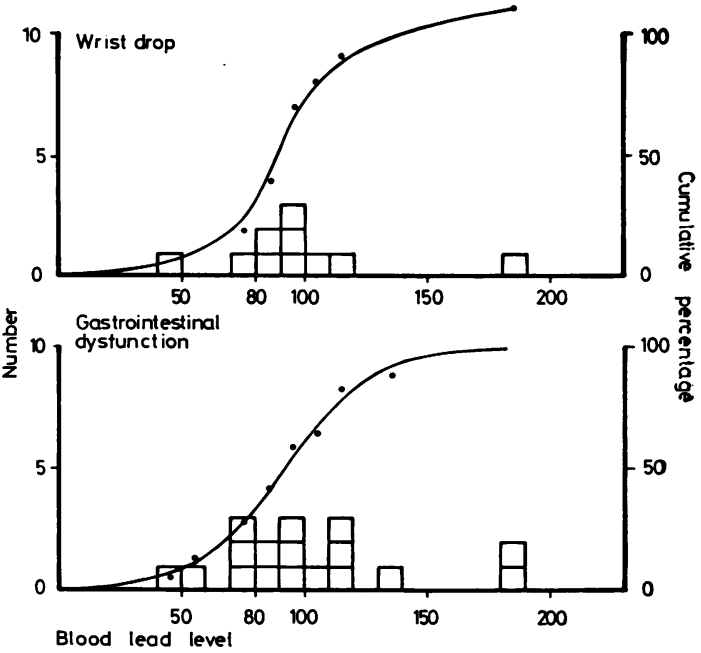

Fig. 1 Number and cumulative percentage of workers with symptoms and signs, by blood lead level, Memphis, Tennessee, 1975.

Table 3 Distribution of symptoms according to blood lead levels of employees, Tennessee Smelter, November 1975

\begin{tabular}{|c|c|c|c|c|}
\hline \multirow[t]{2}{*}{ Symptoms } & \multirow[t]{2}{*}{ Present/absent } & \multirow[t]{2}{*}{ Number of employees } & \multicolumn{2}{|c|}{ Blood lead level } \\
\hline & & & Mean $(\mu g / d l)$ & $(\mu \mathrm{mol} / \mathrm{l})$ \\
\hline Gastrointestinal symptoms ${ }^{1}$ & $\begin{array}{l}\text { Present } \\
\text { Absent }\end{array}$ & $\begin{array}{l}17 \\
61\end{array}$ & $\begin{array}{c}101 \cdot 24^{*} \\
65 \cdot 98\end{array}$ & $\begin{array}{l}4 \cdot 89 * \\
3 \cdot 18\end{array}$ \\
\hline Abdominal pain & $\begin{array}{l}\text { Present } \\
\text { Absent }\end{array}$ & $\begin{array}{l}13 \\
65\end{array}$ & $\begin{array}{c}100 \cdot 77^{*} \\
68 \cdot 25\end{array}$ & $\begin{array}{l}4 \cdot 86^{*} \\
3 \cdot 29\end{array}$ \\
\hline Neuromuscular symptoms ${ }^{2}$ & $\begin{array}{l}\text { Present } \\
\text { Absent }\end{array}$ & $\begin{array}{l}21 \\
57\end{array}$ & $\begin{array}{l}94.52 * \\
65.98\end{array}$ & $\begin{array}{l}4 \cdot 56^{*} \\
3 \cdot 18\end{array}$ \\
\hline Anorexia & $\begin{array}{l}\text { Present } \\
\text { Absent }\end{array}$ & $\begin{array}{l}18 \\
60\end{array}$ & $\begin{array}{l}93 \cdot 89 * \\
67 \cdot 60\end{array}$ & $\begin{array}{l}4 \cdot 53 \\
3.26\end{array}$ \\
\hline Joint pains & $\begin{array}{l}\text { Present } \\
\text { Absent }\end{array}$ & $\begin{array}{l}22 \\
56\end{array}$ & $\begin{array}{l}92 \cdot 59^{*} \\
66.23\end{array}$ & $\begin{array}{l}4 \cdot 47^{*} \\
3 \cdot 20\end{array}$ \\
\hline Constitutional complaints & $\begin{array}{l}\text { Present } \\
\text { Absent }\end{array}$ & $\begin{array}{l}31 \\
47\end{array}$ & $\begin{array}{l}88 \cdot 68 \\
63 \cdot 11\end{array}$ & $\begin{array}{l}4 \cdot 28 \\
3 \cdot 05\end{array}$ \\
\hline
\end{tabular}

* Significant difference ( $P<0.01$, one-tailed test).

Nausea, vomiting, diarrhoea, and/or constipation.

Myalgia, tremor, and/or extensor palsy.

Fatigue, insomnia, irritability, and/or headache. 
Table 4 Prevalence of signs and symptoms by blood lead level. Tennessee Smelter-November 1975

\begin{tabular}{|c|c|c|c|c|c|c|}
\hline \multicolumn{2}{|c|}{ Blood lead level } & \multirow{2}{*}{$\begin{array}{l}\text { Number of } \\
\text { workers }\end{array}$} & \multicolumn{4}{|c|}{ Number and $\%$ prevalence } \\
\hline$(\mu \mathrm{mol} / \mathrm{l})$ & $(\mu g / d l)$ & & $\begin{array}{l}\text { Ex } \\
\text { wed }\end{array}$ & $\begin{array}{l}\text { ensor muscle } \\
\text { kness }\end{array}$ & $\begin{array}{l}\text { Gas } \\
\text { dys }\end{array}$ & $\begin{array}{l}\text { trointestinal } \\
\text { unction* }\end{array}$ \\
\hline $\begin{array}{r}<1.93 \\
1.93-2.85 \\
2.90-3.81 \\
\geq 3.86\end{array}$ & $\begin{array}{l}<40 \\
40-59 \\
60-79 \\
\geq 80\end{array}$ & $\begin{array}{l}14 \\
12 \\
26 \\
26\end{array}$ & $\begin{array}{l}0 \\
1 \\
1 \\
8\end{array}$ & $\begin{array}{l}(-) \\
(8 \%) \\
(4 \%) \\
(31 \%)\end{array}$ & $\begin{array}{r}0 \\
2 \\
3 \\
12\end{array}$ & $\begin{array}{l}(-) \\
(17 \%) \\
(12 \%) \\
(46 \%)\end{array}$ \\
\hline Total & & 78 & 10 & $(13 \%)$ & 17 & $(22 \%)$ \\
\hline
\end{tabular}

*Includes nausea, vomiting, diarrhoea, or constipation.

$\mu \mathrm{mol} /$ litre $(80-99 \mu \mathrm{g} / \mathrm{dl})$, and by all $12(100 \%)$ of those with levels $\geq 4 \cdot 83 \mu \mathrm{mol} /$ litre $(100 \mu \mathrm{g} / \mathrm{dl})$.

In the lead chemicals plant, no correlation was found between symptom prevalence rates and blood lead levels. Potential confounding factors were, however, the long duration of workers' exposure to lead and the use of oral chelation therapy until two months before our evaluation.

RELATION OF BLOOD LEAD LEVELS TO HAEMATOLOGICAL ABNORMALITIES

EP concentrations were found to correlate positively $(r=0.76)$ with blood lead levels. Increases in EP concentrations above background values were first seen at blood lead levels of 1.93-2.90 $\mu \mathrm{mol} /$ litre (40-60 ug/dl) (Figure 2).

Anaemia, defined as a haemoglobin concentration of $<8.69 \mathrm{mmol} /$ litre $(\mathrm{Hb} / 4)(<14.0 \mathrm{gm} / \mathrm{dl})$ (Thorn et al., 1977), was seen in $27(21 \%)$ of 129 workers whose blood was examined at the three plants (Table 5). Anaemic workers had significantly higher mean blood lead and EP values than non-anaemic workers. Only one anaemic worker had a blood lead level of $<2.90 \mu \mathrm{mol} /$ litre $(<60 \mu \mathrm{g} / \mathrm{dl})$ (Table 5); however, six had blood lead levels of $2 \cdot 90-3 \cdot 81$ $\mu \mathrm{mol} /$ litre $(60-79 \mu \mathrm{g} / \mathrm{dl})$, while the remaining 20 had lead levels $\geq 3.86 \mu \mathrm{mol} /$ litre $(\geq 80 \mu \mathrm{g} / \mathrm{dl})$. At the Tennessee and Utah smelters the frequency of anaemia was observed to increase with duration of employment.

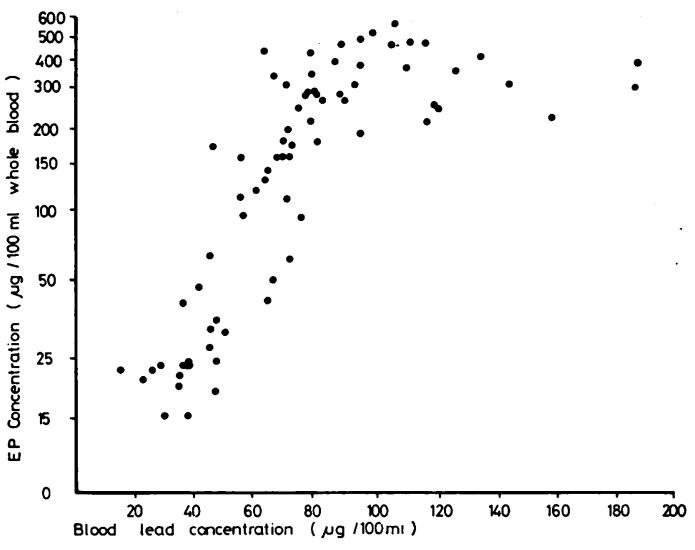

Fig. 2 Blood lead and erythrocyte protoporphyrin levels in workers, Memphis, Tennessee, 1975.

RELATION OF BLOOD LEAD LEVELS TO RENAL FUNCTION ABNORMALITIES

Elevated BUN levels $(\geq 7 \cdot 14 \mathrm{mmol} /$ litre or 20 $\mathrm{mg} / \mathrm{dl})$ were found in six $(8 \%)$ workers in Tennessee, in five $(24 \%)$ of 21 tested in Utah, and in $17(32 \%)$ of the 53 workers evaluated in Missouri. Elevated BUN values ranged from $7 \cdot 50$ to $15 \cdot 71 \mathrm{mmol} /$ litre (21-44 mg/dl). All azotaemic workers, except for three in Utah, had been exposed occupationally to lead for at least four years. Blood lead levels at the time of evaluation were not significantly higher in azotaemic than in non-azotaemic workers.

Detailed evaluations were undertaken of the 17 azotaemic workers discovered at the Missouri plant as well as of two additional men there with borderline elevation of BUN (6.43-6.78 mmol/litre; 18-19 $\mathrm{mg} / \mathrm{dl}$ ) (Table 6). Nine of these 19 workers were found to have previously received courses of oral chelation therapy with ethylenediaminetetraacetic acid (EDTA); six had received multiple courses, and one had been chelated 13 times. Six of the workers evaluated were found to be hypertensive (blood pressure above $140 / 90 \mathrm{mmHg}$,) either by history or during examination. Eight had diminished creatinine

Table 5 Haemoglobin levels by blood lead level, Tennessee, Missouri, and Utah lead plants-1975, 1976

\begin{tabular}{|c|c|c|c|c|c|}
\hline \multicolumn{2}{|l|}{ Haemoglobin level } & \multicolumn{4}{|c|}{ Number $(\%)$ of workers } \\
\hline \multirow[t]{2}{*}{ mmol/litres $(\mathrm{Hb} / 4)$} & \multirow[t]{2}{*}{$(g m / d l)$} & \multicolumn{4}{|c|}{ Blood lead level ( $\mu$ mol/litre $(\mu g / d l)$} \\
\hline & & $(<1.93)(<40)$ & $(1 \cdot 93-2 \cdot 85)(40-59)$ & $(2 \cdot 90-3 \cdot 81)(60-79)$ & $(\geq 3 \cdot 86)(\geq 80)$ \\
\hline $\begin{aligned}<7.45 \\
7.45-8.01 \\
8.07-8.63 \\
8.69-9.25 \\
\geq 9.31\end{aligned}$ & $\begin{aligned}< & 12 \\
& 12 \cdot 0-12 \cdot 9 \\
& 13 \cdot 0-13 \cdot 9 \\
& 14 \cdot 0-14 \cdot 9 \\
\geq & 15 \cdot 0 \\
\text { Total } & \end{aligned}$ & $\begin{array}{r}1(8 \%) \\
11(92 \%) \\
12(100 \%)\end{array}$ & $\begin{array}{r}1(5 \%) \\
3(16 \%) \\
15(79 \%) \\
19(100 \%)\end{array}$ & $\begin{array}{r}2(5 \%) \\
4(9 \%) \\
11(26 \%) \\
26(60 \%) \\
43(100 \%)\end{array}$ & $\begin{array}{r}4(7 \%) \\
4(7 \%) \\
12(22 \%) \\
12(22 \%) \\
23(42 \%) \\
55(100 \%)\end{array}$ \\
\hline
\end{tabular}


Table 6 Results of renal function tests, Missouri lead plant, 1976

\begin{tabular}{|c|c|c|c|c|c|c|c|c|}
\hline Subject & $\operatorname{Age}(y r)$ & $\begin{array}{l}\text { Duration of } \\
\text { lead exposure } \\
(y r)\end{array}$ & $\begin{array}{l}\text { Blood lead } \\
\text { level }(\mu g / d l)\end{array}$ & $\begin{array}{l}B U N^{*} \\
(m g / d l)\end{array}$ & Hypertension & $\begin{array}{l}\text { Creatinine } \\
\text { clearance } \\
\left(m \ln \ln / 1 \cdot 73 \mathrm{~m}^{2}\right)\end{array}$ & $\begin{array}{l}\text { Fasting urine } \\
\text { osmolality } \\
\text { (mosmol/litre) }\end{array}$ & $\begin{array}{l}\text { No. of courses } \\
\text { of oral EDTA** }\end{array}$ \\
\hline 1 & 56 & 7 & 154 & 44 & + & 85 & & 8 \\
\hline 2 & 48 & 20 & 66 & 30 & + & 142 & & 0 \\
\hline 3 & 37 & 20 & 35 & 29 & + & 82 & 871 & 1 \\
\hline 4 & 47 & 23 & 71 & 29 & + & 72 & 588 & 4 \\
\hline 5 & 45 & 8 & 87 & 25 & & 128 & 1020 & 2 \\
\hline 6 & 53 & 23 & 61 & 24 & + & 91 & 1025 & 9 \\
\hline 7 & 52 & 26 & 61 & 25 & + & 115 & 650 & 0 \\
\hline 8 & 38 & 20 & 123 & 22 & & 109 & 608 & 0 \\
\hline 9 & 60 & 25 & 75 & 26 & & 75 & 278 & 0 \\
\hline 10 & 42 & 21 & 66 & 25 & & 96 & 1180 & 0 \\
\hline 11 & 47 & 7 & 48 & 23 & & 108 & 820 & 0 \\
\hline 12 & 53 & 29 & 96 & 20 & & 89 & 708 & 0 \\
\hline 13 & 35 & 13 & 56 & 21 & & 109 & 965 & 0 \\
\hline 14 & 62 & 16 & 105 & 20 & & 97 & 912 & 1 \\
\hline 15 & 52 & 25 & 78 & 23 & & 73 & 286 & 1 \\
\hline 16 & 53 & 20 & 92 & 22 & & 108 & 912 & 13 \\
\hline 17 & 51 & 7 & 80 & 21 & & 65 & 704 & 4 \\
\hline 18 & 52 & 31 & 55 & 19 & & 43 & 652 & \\
\hline 19 & 29 & $4 \cdot 5$ & 58 & 18 & & 112 & 1114 & \\
\hline
\end{tabular}

*Arithmetic mean of duplicate determinations in March and May, 1976.

**EDTA, Ethylene diamine tetraacetic acid chelation therapy.

clearance $\left(<1.52 \mathrm{ml} / \mathrm{s}\right.$ or $<91 \mathrm{ml} / \mathrm{min} / 1.73 \mathrm{~m}^{2}$ body surface area; Thorn et al., 1977). Eight had diminished renal concentrating ability, i.e., inability to concentrate urine to $\geq 800 \mathrm{mosmol} /$ litre after overnight water fast (Hamburger et al., 1968). Urinary $\beta_{2}$-microglobin levels were strikingly elevated in two of these workers (993 and 4890 $\mu \mathrm{g} /$ litre), and normal in all others (Berggard et al., 1968). Urinary amino acid screening by thin-layer chromatography was within normal limits in all 19 men.

\section{Discussion}

In this epidemiological and clinical investigation we examined relationships between blood lead levels and the signs and symptoms of lead toxicity. We were particularly interested in determining whether or not toxicity had occurred in workers with blood lead levels of $1 \cdot 93-3 \cdot 81 \mu \mathrm{mol} /$ litre $(40-79 \mu \mathrm{g} / \mathrm{dl})$. We focused on those exposure levels, because the Occupational Safety and Health Administration in the United States have ruled recently (Occupational Safety and Health Administration, 1978), on the basis of reported toxicity in that range of blood lead levels, that the permissible biological limit for the concentration of lead in the blood of workers must be decreased stepwise over the next five years from the present limit of $3.86 \mu \mathrm{mol} / \mathrm{litre}(80 \mu \mathrm{g} / \mathrm{dl})$ to $2.41 \mu \mathrm{mol} /$ litre $(50 \mu \mathrm{g} / \mathrm{dl})$.

An issue which we had to confront at the outset of the study was whether the blood lead level could be used reliably as an index of lead exposure in groups of workers with varying degrees of absorp- tion of lead. Analyses of the lead content of blood are well known to be subject to numerous biological and analytical sources of error. Biological variation in blood lead results may either be statistically random or it may be systematic in nature (Table 7). Random biological variation may reflect short-term fluctuations in exposure, in absorption, or in the movement of lead to and from bone stores. Systematic biological increases in blood lead levels may be seasonal, may occur during metabolic acidosis, or, most important, may occur in response to chronically increased exposure. Decreases in the blood lead level may occur in anaemia, due to decrease in the red cell mass (to which over $90 \%$ of the blood lead is bound) (Williams, 1966), or as the result of chelation therapy.

Analytical variation in blood lead results may also be either random or systematic. Random intra-laboratory analytical variation was described in a report by Lerner (1975), in which lead values obtained on 35 blind replicate determinations of

Table 7 Potential sources of variability in blood lead. determination

\begin{tabular}{lll}
\hline Incidence & $\begin{array}{l}\text { Type } \\
\text { Biological }\end{array}$ & Analytical \\
\hline Random & $\begin{array}{l}\text { Short-term variation } \\
\text { in exposure, absorption, } \\
\text { or metabolic flux } \\
\text { Systematic }\end{array}$ & $\begin{array}{l}\text { Seasonal increases during } \\
\text { summer } \\
\text { Increases in acidosis, } \\
\text { e.g. with fever, or ketoacidosis } \\
\text { Decreases in anaemia and } \\
\text { after chelation therapy }\end{array}$ \\
\hline
\end{tabular}


aliquots from a single venous blood sample were found to range from 0.58 to $2.03 \mu \mathrm{mol} / \mathrm{litre}(12-42$ $\mu \mathrm{g} / \mathrm{dl}$ ) (mean 19.1; SD $5 \cdot 7 \mu \mathrm{g} / \mathrm{dl}$ ). Inter-laboratory variation, which is more likely to be of a systematic nature (Rose and Blackburn, 1968), has been documented in blood lead analyses by Browne et al. (1974) in Great Britain and by Keppler et al. (1970) in the United States through the technique of simultaneously sending aliquots of a blood sample to a number of laboratories for blind analysis.

It is clear that, in making a clinical diagnosis of lead poisoning, the result of a single blood lead determination must be interpreted with caution. Further, the responses of individual workers to a given internal dose of lead will vary, and mild lead poisoning may occur in the face of a very high blood lead level (Chamberlain and Massey, 1972) or vice versa. A diagnosis of increased lead exposure or of lead poisoning in an individual worker has therefore to be based on full clinical evaluation, on replicate determinations of the blood lead level, and on assessment of lead-related haematological indices, such as erythrocyte protoporphyrin (EP) or $\delta$-aminolevulinic acid.

Nevertheless, the blood lead determination, and even the single determination of the blood lead level, is not without value. Chisolm et al. (1976) have shown by means of a calcium-EDTA mobilisation technique that the concentration of lead in blood reflects closely the concentration of diffusible lead in soft tissue and bone stores; they measured $24 \mathrm{~h}$ urinary lead output in 102 children and adolescents after administration of intramuscular calcium-EDTA ( $25 \mathrm{mg} / \mathrm{kg}$ body weight), and found the coefficient of correlation ( $r$ ) between blood lead and chelatable lead to be $0 \cdot 818$.

Further, analytical variation in blood lead determination may be reduced considerably by careful application of quality control techniques. In a nationwide blood lead proficiency testing programme organised in the United States by the Center for Disease Control $(1975,1976)$, the percentage of laboratories producing acceptable results (within $\pm 15 \%$ of reference means) on $80 \%$ or more of test samples has increased from $35.3 \%$ in 1975 , the first year of the programme's operation, to $51.6 \%$ in 1978.

Finally, the fundamental difference between a clinical diagnosis and an epidemiological survey, namely that the survey draws on data from a number of individuals, helps to reduce the impact on survey results of random variation from both biological and analytical sources. By definition, random variation cancels itself out. Random error will reduce the precision of survey results, but as long as the extent of variation, particularly of random analytical variation, can be monitored, it is a manageable problem and will not produce biased results. Systematic variation is more dangerous, because it can produce bias, and every effort must be made to reduce it (Rose and Blackburn, 1968). However, with careful attention paid to proficiency testing, a single blood lead determination can be a valuable and accurate tool in epidemiological analysis.

In this study, we found a range of blood lead values from low normal, in groups ant:cipated to have low exposure, to extremely elevated in certain categories of production workers. Although we included no formal control group in the study, we were able through application of the toxicological technique of dose-response analysis (Nordberg, 1976) to juxtapose and to compare data from these various exposure groups. In this approach, the groups with lowest exposure serve as an internal control.

We found evidence of clinical and biochemical lead toxicity in workers with blood lead levels of $1.93-2.85 \mu \mathrm{mol} / \mathrm{litre}(40-59 \mu \mathrm{g} / \mathrm{dl})$ and of 2.90 $3.81 \mu \mathrm{mol} /$ litre $(60-79 \mu \mathrm{g} / \mathrm{dl})$. Eleven per cent of workers with extensor muscle weakness or gastrointestinal symptoms had lead levels of 1.93-2.85 $\mu \mathrm{mol} / \mathrm{litre}(40-59 \mu \mathrm{g} / \mathrm{dl})$, and $16 \%$ of workers with those findings had levels of 2.90-3.81 $\mu \mathrm{mol} / \mathrm{litre}$ $(60-79 \mu \mathrm{g} / \mathrm{dl})$. In addition, $26 \%$ of workers with anaemia had levels of less than $3.86 \mu \mathrm{mol} /$ litre ( $<80 \mu \mathrm{g} / \mathrm{dl})$. These data support the OSHA (1978) proposal to lower the permissible biological limit for the blood lead concentration. They are also consistent with the findings of other investigators who have noted clinical (Lilis et al., 1977; Dahlgren, 1978; Irwig et al., 1978), haematological (Roels et al., 1976), and neurological (Seppäläinen et al., 1975; Araki and Honma, 1976) abnormalities in lead workers at blood lead levels below $3.86 \mu \mathrm{mol} /$ litre $(80 \mu \mathrm{g} / \mathrm{dl})$. Much of this information was summarised in a recent review by Nordberg (1976). Our results differ from those of a recent Finnish study (Tola and Nordman, 1977), which found no association between symptom prevalence rates and blood lead concentrations up to lead levels of $3.38 \mu \mathrm{mol} /$ litre $(70 \mu \mathrm{g} / \mathrm{dl})$; however, the authors of that report suggest that lack of specificity in their questionnaire may have contributed to their failure to detect a dose-response relationship.

Our finding of renal dysfunction in 28 workers with occupational exposure to lead, nine of whom gave a past history of oral chelation therapy, parallels the reports of Goyer and Rhyne (1973), Lilis et al. (1968), and Wedeen et al. (1975) and resembles the experience in moonshine whiskey drinkers described by Ball and Sorensen (1969). All of those 
studies suggest that relatively prolonged, high-dose lead exposure is required to produce lead nephropathy; it has also been suggested that repeated use of oral chelation therapy in subjects with chronic exposure to lead may enhance the severity of the renal effects of lead. The natural history of lead nephropathy is poorly understood; however, a recent cohort study of 7032 lead smelter and lead battery workers in the United States (Cooper and Gaffey, 1975) found evidence of excess mortality rates in both groups (standardised mortality ratios of 264 and 175, respectively) from chronic nephritis. Nordberg (1976) suggests that BUN levels might begin to increase in a small proportion of lead workers at blood lead levels of $5.79 \mu \mathrm{mol} / \mathrm{litre}(120$ $\mu \mathrm{g} / \mathrm{dl}$ ), and that approximately $50 \%$ of workers might suffer such impairment at lead levels of $7 \cdot 72 \mu \mathrm{mol} /$ litre $(160 \mu \mathrm{g} / \mathrm{dl})$.

We encountered an unexpectedly high prevalence of frank lead poisoning in this investigation. Although the three plants in which these cases occurred may have come to our attention because exposures in them were atypically poorly controlled, they are by no means unique in the United States, and there is no way in which the existence of the working conditions found in them can be justified in a modern and humane society. The basic technology for the control of airborne lead in the workplace has been understood for decades. Somewhat ruefully, we are reminded of the observation of Alice Hamilton in 1914 that:

'Only a few years ago, most of us were under the impression that our country was practically free from occupational poisoning . . . that our lead works were so much better built and managed, our lead workers so much better paid, and therefore better fed, ... that lead poisoning was not a problem here as it is in all other countries ... As a matter of fact, the supposed advantages ... obtain only in a few of the trades ... that far from being superior .... in the matter of industrial plumbism, we have a higher rate in many of our lead industries than have England or Germany.'

It is to be hoped that widespread and enlightened compliance with the lead exposure regulations issued recently by the Occupational Safety and Health Administration (OSHA, 1978) will bring to an end the most serious sorts of lead exposure observed in this study. In addition, full attainment of the new standards is expected greatly to reduce the incidence of the subtler manifestations of lead toxicity which have been observed in this and in other evaluations of workers with blood lead levels of $1.93-3.86 \mu \mathrm{mol} /$ litre $(40-80 \mu \mathrm{g} / \mathrm{dl})$. Future evaluations of workers whose lead exposures have remained within the limits set by the new regulations will, however, be required to assess the success of these standards in minimising industrial lead toxicity.

We would like to acknowledge, with thanks, the help of Mitchell Singal, MD, John Baker, and David Browning, Jr, MD.

\section{References}

Araki, S., and Honma, T. (1976). Relationships between lead absorption and peripheral nerve conduction velocities in lead workers. Scandinavian Journal of Work, Environment and Health, 4, 225-231.

Baker, E. L., Jr., Folland, D. S., Taylor, T. A., Frank, M., Peterson, W., Lovejoy, G., Cox, D., Housworth, J., and Landrigan, P. J. (1977). Lead poisoning in children of lead workers: home contamination with industrial dust. New England Journal of Medicine, 296, 260-261.

Ball, G. V., and Sorensen, L. B. (1969). Pathogenesis of hyperuricemia in saturnine gout. New England Journal of Medicine, 280, 1199-1202.

Berggard, I., and Bearn, A. G. (1968). Isolation and properties of a low molecular weight $\beta_{2}$-globulin occurring in human biologic fluids. Journal of Biological Chemistry, 243, 4095-4099.

Browne, R. C., Ellis, R. W., and Weightman, D. (1974). Interlaboratory variation in measurement of blood lead levels. Lancet, 2, 1112-1113.

Center for Disease Control (1975, 1976). Blood Lead Proficiency Testing-1975 Data Summary. Blood Lead Proficiency Testing-1976 Data Summary. US Department of Health, Education and Welfare, Public Health Service, Center for Disease Control: Atlanta, Georgia.

Chamberlain, M. J., and Massey, P. M. O. (1972). Mild lead poisoning with an excessively high blood lead. British Journal of Industrial Medicine, 29, 458-460.

Chisolm, J. J., Jr., Mellits, D., and Barrett, M. B. (1976). Interrelationships among blood lead concentration, quantitative daily ALA-U and urinary lead output following calcium EDTA. In Effects and Dose Response Relationships of Toxic Metals, pp. 416-433. Edited by G. F. Nordberg. Elsevier Scientific Publishing Co.: Amsterdam.

Cooper, W. C., and Gaffey, W. R. (1975). Mortality of lead workers. Journal of Occupational Medicine, 17, 100-107.

Dahlgren, J. (1978). Abdominal pain in lead workers. Archives of Environmental Health, 21, 156-159.

Giguere, C. G., Howes, A. B., McBean, M., Watson, W. N., and Witherell, L. E. (1977). Increased lead absorption in children of lead workers, Vermont. Center for Disease Control Morbidity and Mortality Weekly Report, 26, 61-62.

Goyer, R. A., and Rhyne, B. (1973). Pathological effects of lead. International Review of Experimental Pathology, 12, 1-77.

Hamburger, J., Richet, G., Crosnier, J., Funck-Brentano, J. L., Antoine, B., DuCrot, H., Mery, J. P., and de Montera, H. (1968). Nephrology, Volume I, pp. 170-172. Translated by A. Walsh. W. B. Saunders Co: Philadelphia. Hamilton, A. (1914). Lead poisoning in the United States, American Journal of Public Health, 4, 477-480.

Irwig, L. M., Harrison, W. O., Rocks, P., Webster, I., and Andrew, M. (1978). Lead and morbidity: a dose-response relationship. Lancet, 2, 4-7.

Keenan, R. G., Byers, D. H., Saltzman, B. F., and Hyslop, F. L. (1963). The 'USPHS' method for determining lead 
in air and in biological materials. American Industrial Hygiene Association Journal, 24, 481-491.

Keppler, J. F., Mayfield, M. E., Moss, W. D., Tietjen, G., and Linch, A. L. (1970). Interlaboratory evaluation of the reliability of blood lead analyses. American Industrial Hygiene Association Journal, 31, 412-423.

Landrigan, P. J., Gehlbach, S. H., Rosenblum, B. F., Shoults, J. M., Candelaria, R. M., Barthel, W. F., Liddle, J. A., Smrek, A. L., Staehling, N. W., and Sanders, J. F. (1975). Epidemic lead absorption near an ore smelter: the role of particulate lead. New England Journal of Medicine, 292, 123-129.

Landrigan, P. J., Baker, E. L., Jr., Feldman, R. G., Cox, D. H., Eden, K. V., Orenstein, W. A., Mather, J. A., Yankel, A. J., and Von Linden, I. H. (1976). Increased lead absorption with anemia and slowed nerve conduction in children near a lead smelter. Journal of Pediatrics, 89, 904-910.

Lerner, S. (1975). Blood lead analysis-precision and stability. Journal of Occupational Medicine, 17, 153-154.

Levine, R. J., Moore, R. M., McLaren, G. D., Barthel, W. F., and Landrigan, P. J. (1976). Occupational lead poisoning, animal deaths, and environmental contamination at a scrap smelter. American Journal of Public Health, 66, 548-552.

Lilis, R., Gavrilescu, N., Nestorescu, B., Dumitriu, C., and Roventa, A. (1968). Nephropathy in chronic lead poisoning. British Journal of Industrial Medicine, 25, 196-202.

Lilis, R., Fischbein, A., Eisinger, J., Blumberg, W. E., Diamond, S., Anderson, H. A., Rom, W., Rice, C., Sarkozi, L., Kon, S., and Selikoff, I. J. (1977). Prevalence of lead disease among secondary lead smelter workers and biological indicators of lead exposure. Environmental Research, 14, 255-285.

Medical Research Council (1975). Aids to the Examination of the Peripheral Nervous System. Memorandum No. 45, 1975. Her Majesty's Stationery Office: London.

Nordberg, G. (1976). Effects and dose-response relationships of toxic metals. In Proceedings from an International Meeting Organised by the Sub-Committee on the Toxicology of Metals of the Permanent Commission and International Association on Occupational Health, Tokyo, November 18-23, 1974, pp. 7-95. Elsevier Scientific Publishing Co: Amsterdam.

Occupational Safety and Health Administration (1976). OSHA Standardized Method for Sampling Total Dust,
Metal Fumes, and Liquid Aerosols. US Department of Labor: Washington.

Occupational Safety and Health Administration, US Department of Labor (1978). Occupational exposure to lead, final standard. Federal Register, 43, 52952-53014, 14 November 1978.

Ordoñez, B. R., Romero, L. R., and Mora, R. (1976). Investigacion epidemiologica sobre niveles de plomo en el poblacion infantil y en el medio ambiente domiciliario de Ciudad Juarez, Chihuahua en relacion con una fundicion de El Paso, Texas. Boletin De La Oficina Sanitaria Panamericana, 80, 303-317.

Piomelli, S. (1973). A micromethod for free erythrocyte porphyrins: the FEP test. Journal of Laboratory and Clinical Medicine, 81, 932-940.

Roels, H., Buchet, J.-P., Lauwerys, R., Hubermont, G., Bruaux, P., Claeys-Thoreau, F., LaFontaine, A., and Van Overschelde, J. (1976). Impact of air pollution by lead on the heme biosynthetic pathway in school-age children. Archives of Environmental Health, 31, 310-316.

Rose, G. A., and Blackburn, H. (1968). Cardiovascular Survey Methods. World Health Organization: Geneva.

Seppäiäinen, A. M., Tola, S., Hernberg, S., and Kock, B. (1975). Subclinical neuropathy at 'safe' levels of lead exposure. Archives of Environmental Health, 30, 180-183.

Shārfinski, J. (1974). Lead in blood with Delves technique after the addition of $\mathrm{NH}_{4} \mathrm{Cl}$. Atomic Absorption, 10, 119-124.

Thorn, G. W., Adams, R. A., and Braunwald, E. (editors) (1977). Harrison's Principles of Internal Medicine. McGrawHill: New York.

Tola, S., and Nordman, D.-H. (1977). Subjective symptoms and exposure to lead. International Archives of Occupational and Environmental Health, 40, 153-162.

Wedeen, R. P., Maesaka, J. K., Weiner, B., Kipat, G. A.. Lyons, M. M., Vitale, L. F., and Joselow, M. M. (1975), Occupational lead nephropathy. American Journal of Medicine, 59, 630-641.

Williams, M. K. (1966). Blood lead and haemoglobin in lead absorption. British Journal of Industrial Medicine, 23, 105-111.

Winegar, D. A., Levy, B. S., Andrews, J. S., Jr., Landrigan, P. J., Scruton, W. H., and Krause, M. J. (1977). Chronic occupational exposure to lead: an evaluation of the health of smelter workers. Journal of Occupational Medicine, 19, 603-606. 